\title{
RELATIONSHIP BETWEEN ISO 9001 CERTIFICATION MATURITY AND EFQM BUSINESS EXCELLENCE MODEL RESULTS
}

\author{
DOI: 10.12776/QIP.V19I1.556
}

\author{
LUIS MIGUEL CIRAVEGNA FONSECA
}

Received 20 March 2015, Revised 14 April 2015, Accepted 30 May 2015

\begin{abstract}
Purpose: This exploratory research evaluates if there is a relationship between the number of years since an organization has achieved ISO 9001 certification and the highest level of recognition received by the same organization with the EFQM Business Excellence Model.

Methodology/Approach: After state of the art review a detailed comparison between both models was made. Fifty two Portuguese organizations were considered and Correlation coefficient Spearman Rho was used to investigate the possible relationships.
\end{abstract}

Findings: Conclusion is that there is indeed a moderate positive correlation between these two variables, the higher the number of years of ISO 9001 certification, the higher the results of the organization EFQM model evaluation and recognition. This supports the assumption that ISO 9001 International Standard by incorporating many of the principles present in the EFQM Business Excellence Model is consistent with this model and can be considered as a step towards that direction.

Research Limitation/implication: Due to the dynamic nature of these models that might change over time and the possible time delays between implementation and results, more in-depth studies like experimental design or a longitudinal quasi-experimental design could be used to confirm the results of this investigation.

Originality/Value of paper: This research gives additional insights on conjunct studies of both models. The use of external evaluation results carried out by the 
independent EFQM assessors minimizes the possible bias of previous studies accessing the value of ISO 9001 certification.

Keywords: ISO 9001; Quality Management System; certification; TQM; EFQM Business Excellence Model

\section{INTRODUCTION}

Quality Management can be seen as a management philosophy, that has evolved from a narrow and mechanic perspective known has Statistical Quality Control, to Quality Assurance and then to a more broader and holistic one, known as Total Quality Management (TQM) and Business Excellence (Dahlgaard-Park, 2008).

Due to an increasingly demanding competitive environment, many organizations have relied on Quality Management Systems, either to respond to external stakeholder pressures or to internal motivations for changes aiming to increased performance. ISO 9001 International Standards and EFQM Business Excellence Model are two of the most relevant approaches available for those purposes.

This exploratory research tries to evaluate if there is a relationship between the number of years since an organization has achieved ISO 9001 certification, with the highest level of recognition received by the same organization applying the EFQM Business Excellence Model (BEM). EFQM BEM is considered a more mature and demanding model, with multi-stakeholder perspectives, emphasis on innovation, flexibility, and benchmarking and action oriented key business results. Therefore, it could be used as a measurement system for organizations Quality management maturity, as it level evolves within the ISO 9001 Plan-DoCheck-Act cycles.

Although there is considerable literature addressing both ISO 9001 and EFQM models implementation, motivations and results, it is not common to study both in conjunction and there are still some gaps to be addressed.

Moreover, each model as its own defenders (some will argue that ISO 9001 certification is more concerned with conformity with standards requirements and EFQM Business Excellence Model assessments with finding and applying improvement opportunities), and it is not common to measure the improvements achieved by organizations with ISO 9001 implementation and certification, with Business Excellence Models.

After literature review, a critical comparative analysis between ISO 9001 International Standard and the EFQM Business Excellence Model is made, followed by a quantitative study using correlation analysis of the Portuguese organizations that have achieved EFQM recognition and are ISO 9001 certified.

The paper ends by presenting the research results and the proposed conclusions that support the proposition that there is a moderate positive relationship between these two Quality Management approaches. 


\section{METHODOLOGY}

The research methodology for this exploratory Research paper was based on the prescriptions of Marconi and Lakatos (2003) and comprehended the following steps:

- Study and objectives definition;

- Literature Review;

- Data research and collection;

- Results analysis;

- Conclusion.

\section{ISO 9001 AND EFQM BUSINESS EXCELLENCE MODEL LITERATURE REVIEW}

\subsection{ISO 9001 International Standard}

The ISO 9000 series of International Standards were first published by ISO $^{\odot}$ (ISO, 2014) back in 1987 as a key tool to allow for the growing internationalization of business and the need for common quality management system standards. ISO always tried to stress that "output matters" but it should be acknowledge that there are organizations that look into ISO 9001 and the certification of their Quality Management Systems more due to external reasons than a real and effective business improvement model that in fact can be (Levine and Toffel, 2010).

ISO 9001:2008 is based on a PDCA (Plan-Do-Check-Act) approach (Figure 1, source: ISO 9001:2008 International Standard) and on the following eight quality management principles that have been identified and can be used by top management to lead the organization towards improved performance (ISO 9000:2005 International Standard):

- Customer focus;

- Leadership;

- Involvement of people;

- Process approach;

- System approach to management;

- Continual improvement;

- Factual approach to decision-making;

- Mutually beneficial supplier relationships, 

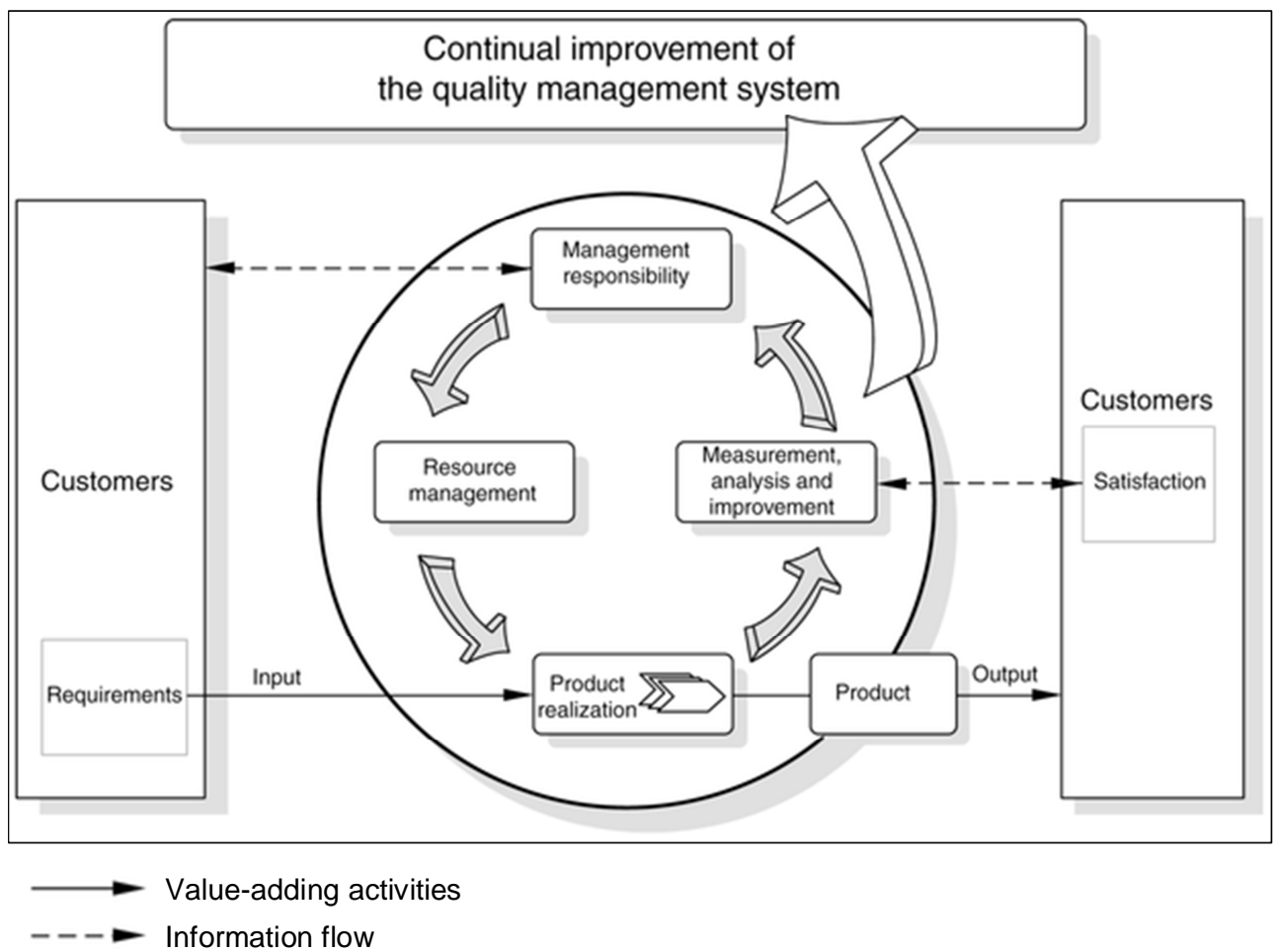

Figure 1 - Model of a process-based quality management system

As per Figure 2, ISO 9001:2008 International Standard has achieved great international visibility with more than 1 Million Organizations with ISO 9001 certified Management Systems all over the world accordingly to ISO Survey 2013 (ISO, 2014). 


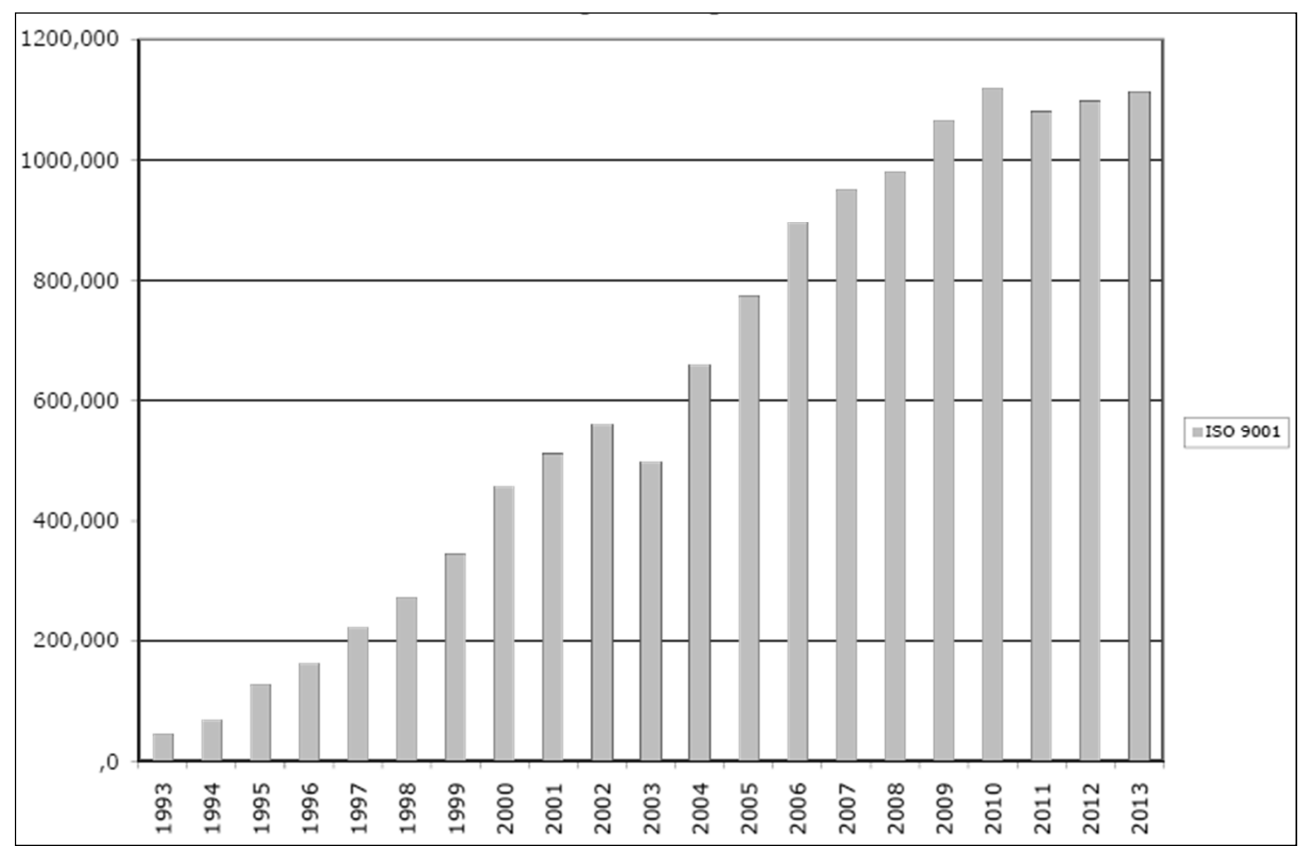

Figure 2 - ISO 9001 Certified Organizations Survey Trends

Karapetrovic, Casadesus and Heras (2008) identified 115 empirical studies that employ surveys with the purpose of studying the impact of ISO 9000 standards worldwide. Scientific studies (Boiral, 2012), have linked the success in the implementation of ISO 9001 Quality Management Systems (QMS) to the organization motivations (most significant results when the motivations are internal rather than external) and to the way the standard is interpreted and implemented. Levine and Toffel (2010, Harvard Business School) analyzed 1000 organizations of which 500 with QMS implemented and certified and 500 without QMS implemented and certified. They concluded that the first presented a set of indicators significantly more favorable than the others: $9 \%$ higher sales volume and consequent additional profits; more employment $(10 \%)$ and better wages $(7 \%)$ due to higher sales volumes and profitability, and in combination with ISO 14001 (Environmental Management Standard) less waste and incidents (these effects are more pronounced in small organizations).

From an academic point, more recently studies by Tarí, Molina-Azorín and Heras (2012) also suggest that ISO 9001 has clear benefits on organizational, operational, people and customer results and that the effects on financial performance are inconclusive. However, this paper does acknowledge that other studies have reached different conclusions and suggests that variables related to the reasons for certification should be included in future research studies. Also accordingly to Yin and Schmeidler (2009) standardized management systems may be implemented in very different ways depending on organizations, which might explain the heterogeneous performance of these standardized systems and these authors stress that the studies of the impacts of ISO 9001 certification have 
largely neglected this phenomenon. In light of these conclusions the author will like to add his own personal perspective on the issue, supported on more than 20 years' experience in the certification business:

- There are considerable methodological differences and control variables on studies concerning ISO 9001 certification impacts.

- We need to understand the conditions under wish ISO 9001 certification benefits organizational environmental and overall performance.

- Certification to ISO 9001 should be a result of a well implemented Quality Management System, not just "certification".

- ISO 9001:2008 (and future ISO 9001:2015 even more) do have some challenges for the auditors, e.g., how much improvement is enough? Additionally there is some variation between Certification Bodies approaches and practices, in relation to global coverage, level of expertise, audit practices, and rigor.

- In summary, certification is indeed a measure of QMS implementation intensity but we need to take into consideration how variations in QMS implementation may affect performance results.

These considerations fully support Heras and Boiral (2013) position that "further critical and rigorous empirical studies are necessary in order to analyze the real perceptions of the various stakeholders (consumers, managers, suppliers, intermediary clients, workers and public administration) regarding the adoption of meta-standards and their effects".

A remark should be made that ISO has a Directive governing the publication of standards (to be reviewed every 5 years) and a revision of ISO 9001 is under way, with the release of the future ISO 9001:2015 International Standard expect for last quarter of 2015. Based on DIS (Draft International Standard) version, we can expect that the following ideas will be reinforced or introduced (Fonseca, 2015):

1) More emphasis on process approach and less on documentation.

2) After considerable discussion, products and services were chosen versus goods and services, requiring a further update of terminology.

3) Risk-based thinking was introduced giving additional credibility to ISO 9001 within business and top Management by adding some systematic evaluation of potential and actual issues with the aim of making processes more robust and capable.

4) The organizational context should be considered and interested parties concept was also introduced but with the precaution we are referring to relevant parties that must have some actual or potential impact on the quality of products and services. 
5) Concepts like change control and strategic direction will be reinforced on the future ISO 9001:2015 standard, trying to further approach and embed ISO 9001 and business management.

These changes will bring the future ISO 9001:2015 closer to Business Excellence Models like EFQM.

\subsection{EFQM Business Excelence Model}

There are a considerable number of studies on the impact of Business Excellence Models, being the EFQM model one that is addressed with most relevance (Sila and Ebrahimpour, 2005; Heras, 2006). Accordingly to previous research organizations implementing Total Quality Management (TQM)/Business Excellence model (BEM) will obtain both increased financial profit (Boulter, Bendell and Dahlgaard, 2013; Jacob, Madu, and Tang, 2004; Hansson and Eriksson, 2002) and improved non-financial outcomes (Curkovic, et al. 2000; Powell, 1995).

EFQM is a non-profit foundation, based in Brussels that was formed in 1988 by a group of leading European organizations. EFQM is the custodian of the EFQM Business Excellence Model.

The EFQM model has been realized by a relatively small number of top managers and aims toward Top Management with the key message that business excellence is the key for sustainable organizational success. The model is used to evaluate organizations progress towards excellence (Gutiérrez, Torres and Molina, 2010; George, Cooper and Douglas, 2003) and as a guideline to measure and improve traditional Total Quality Management (Kim, Kumar and Murphy, 2008).

The EFQM model is now with the 2013 version. EFQM states that more than 30,000 Organizations are using the EFQM Excellence Model and have evolved towards a stronger stakeholder, sustainability and agility approaches while emphasizing benchmarking and the need for change and adaptability to achieve sustainable success (Fonseca, 2015): in line with the statement often attributed to the famous scientist Charles Darwin (1809-1882) "It is not the strongest of the species that survives, nor the most intelligent... But the one that is the most adaptable to change".

EFQM (EFQM, 2012a) defines excellent organizations "as the ones that achieve and sustain outstanding levels of performance that meet or exceed the expectations of all their stakeholders" and the EFQM Model ${ }^{\odot} 2013$ (EFQM, 2012c) is based on the following elements:

- The Fundamental Concepts of Excellence (EFQM, 2012b) that define the underlying principles that form the foundation for achieving sustainable excellence in any organization. In the 2013 version these are: "adding value for customers, creating a sustainable future, developing 
organisational capability, harnessing creativity and innovation, leading with vision, inspiration \& integrity, managing with agility, succeeding through the talent of people and sustaining outstanding results".

- The Model Criteria, based on Enablers and Results, that define the underlying principles that form the foundation for achieving sustainable excellence in any organization.

- And the Radar that is a tool for driving systematic improvement in all areas of the organization. This includes scoring matrices for Enablers and Results and is complemented with a global scoring range for the full model criteria, between 0 and 1000 points.

Figure 3 bellow presents the actual Model Criteria of the 2013 version (source: an Overview of the EFQM Model, 2012c):

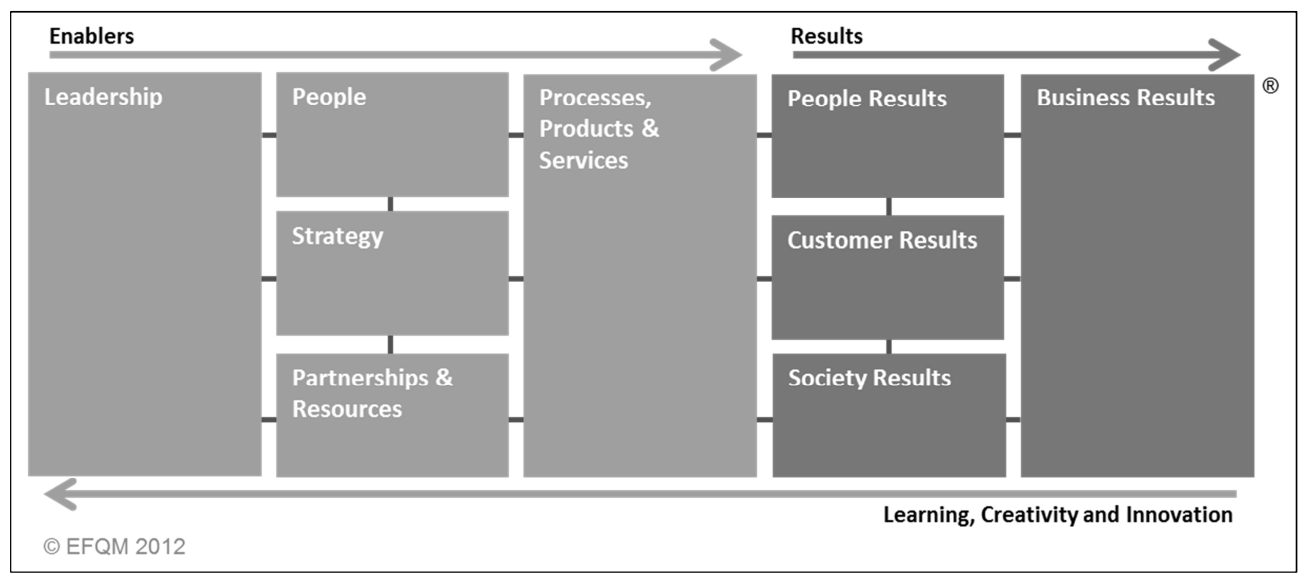

Figure 3 - EFQM ${ }^{\odot} 2013$ Business Excellence Model

According to EFQM (2015) "to achieve sustained success, an organisation needs strong leadership and clear strategic direction. They need to develop and improve their people, partnerships and processes to deliver value-adding products and services to their customers. In the EFQM Excellence Model, these are called the Enablers. If the right Enablers are effectively implemented, an organisation will achieve the Results they, and their stakeholders, expect".

Since the EFQM model was launched in 1991 to support the European Quality Award, it has undergone several revisions and updates (EFQM, 2012c):

- In 1999, the Fundamental concepts and the Radar were introduced.

- In 2003, the concept of "Public Responsibility" becomes "Corporate Social Responsibility".

- In 2010 there as an increased focus on future performance including "Sustainability and Risk Management" and some changes to the model 
criteria (e.g., "Process" becomes "Processes, Products and Services" and weighting for the criteria was changed with all becoming $10 \%$ except "Customer Results" with 15\% and "Key Results" with 15\%).

- In 2013, a new revised version was introduced with more focus on Flexibility and Agility, including scenario planning and organizational development. "Key Results" becomes "Business Results" and Concepts become "action oriented".

According to EFQM, the model helps organizations to access their performance, to identify strengths and improvement areas, to integrate existing tools, procedures and processes by introducing a new way of thinking that focused on identifying actions that drive results. Academics like Dahlgaard-Park (2008) do support the view of EFQM Business Excellence Model brings relevant benefits for organizations, like a holistic and integrated approach, defined relationships between approaches and results and reinforced system dynamics. For others like Van der Wiele, Williams and Dale (2000), these models contribute to a better understanding and application of TQM, foster benchmarking and the identification of improvements while allowing the measurement of achieved results.

Any organization can be recognized through an assessment based on the EFQM Excellence Model based on a continuous maturity framework:

- EFQM Committed to Excellence (less than 300 global scoring points) is developed to introduce organizations to business excellence.

- Next recognition level is EFQM Recognised for Excellence (300-500 global scoring points) with an externally validated analysis of organization's performance recognising the achievements made (evaluations with more than 300 points are required to issue a certificate).

- Highest level is the EFQM Excellence Award that aims to recognise Europe's best performing organizations, whether private, public or nonprofit, that have a consistent track record of success in turning strategy into action and continuously improving their performance (higher than 500 global scoring points). Within this category there are three sub-levels, starting with Excellence Award Finalist, Excellence Award Silver Prize and Excellence Award Gold Prize.

\subsection{ISO 9001 International Standard relationship with EFQM Business Excellence Model}

Although ISO 9001 International Standard cannot be considered as a TQM or a Business Excellence Model it does indeed incorporate many of the principles of these models and can be considered as a step towards that direction (MartinezCosta et al, 2009). There are common dimensions between ISO 9001 
International Standards and TQM (e.g., process management), however companies that implemented and certified their ISO 9001:2000 Management Systems would still fall far short of implementing a comprehensive TQM system (Martinez-Costa et al, 2009). But we should remark that after the 2000 revision, the 2008 version has already being issued and it is exactly one of the aims of the future ISO 9001:2015 to close even further this gap between ISO and TQM. The basic core principles of TQM are still present and alive and the future ISO 9001:2015 International Standard should be a step towards TQM.

An overview of a comparison between the requirements of ISO 9001:2008 International Standard and EFQM 2013 Business Excellence Model is presented in Table 1.

Table 1 - Comparison between ISO 9001:2008 and EFQM Business Excellence Model (2013)

\begin{tabular}{|c|c|c|}
\hline EFQM Criteria & $\begin{array}{l}\text { ISO 9001:2008 } \\
\text { Requirements }\end{array}$ & $\begin{array}{l}\text { Comments: author assessment on the } \\
\text { intensity coverage of EFQM model by } \\
\text { ISO 9001:2008 }\end{array}$ \\
\hline 1. Leadership & $\begin{array}{l}\text { 5.1 Management } \\
\text { commitment } \\
\text { 5.5 Responsibility, } \\
\text { authority and } \\
\text { communication } \\
\text { 5.6 Management review }\end{array}$ & Partially Covered \\
\hline 2. Strategy & $\begin{array}{l}\text { 5.2 Customer focus } \\
\text { 5.3 Quality policy } \\
\text { 5.4 Planning }\end{array}$ & Partially Covered \\
\hline 3. People & $\begin{array}{l}6.2 \text { Human resources } \\
6.4 \text { Work environment }\end{array}$ & Weakly covered \\
\hline $\begin{array}{ll}\text { 4. } & \text { Partnerships and } \\
\text { Resources }\end{array}$ & $\begin{array}{l}\text { 6.1 Provision of resources } \\
6.3 \text { Infrastructure } \\
7.4 \text { Purchasing }\end{array}$ & Partially Covered \\
\hline 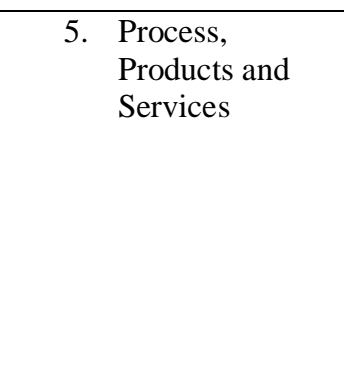 & $\begin{array}{l}\text { 7 Product realization } \\
\text { 8.2.2 Internal audit } \\
\text { 8.2.3 Monitoring and } \\
\text { measurement of processes } \\
\text { 8.3 Control of } \\
\text { nonconforming product } \\
\text { 8.5 Improvement }\end{array}$ & Considerable Covered \\
\hline $\begin{array}{ll}\text { 6. } & \text { Customer } \\
& \text { Results }\end{array}$ & $\begin{array}{l}\text { 8.2.1 Customer } \\
\text { satisfaction }\end{array}$ & Partially Covered \\
\hline
\end{tabular}




\begin{tabular}{|c|l|l|}
\hline EFQM Criteria & $\begin{array}{l}\text { ISO 9001:2008 } \\
\text { Requirements }\end{array}$ & $\begin{array}{l}\text { Comments: author assessment on the } \\
\text { intensity coverage of EFQM model by } \\
\text { ISO 9001:2008 }\end{array}$ \\
\hline $7 . \quad$ People Results & -- & Not covered \\
\hline $8 . \quad$ Society Results & -- & Not covered \\
\hline $9 . \quad$ Key Results & 8.4 Analysis of data & Partially Covered \\
\hline
\end{tabular}

As Karapetrovic, Casadesus and Heras (2008) concluded it is difficult to compare the results and draw conclusions between ISO 9001 and EFQM BEM studies due to different methodology approaches (e.g., attributes to be measured, variables, scales of measurement). There are articles that address both ISO 9001 and EFQM BES model (e.g. Kiauta, 2012) but Heras, Casadesus and Marimón (2011) found no study performing a comparative analysis of the impact of both ISO 9001 and EFQM management frameworks concluding that it is very difficult to compare their impact directly. In order to fulfill this gap, Heras et al (2013) made a research using a survey with the participation of more than one hundred quality survey of and data from more than two hundred external evaluations carried out between 1998 and 2007 in Spanish organizations that have adopted the EFQM model. Results showed that the motivations of the organizations to adopt the international ISO 9001 standard were both internal and external while the ones for using the EFQM model were generally internal. Accordingly to the assessors the companies that were certified with ISO 9001International Standard scored higher in the EFQM model than those that were not certified, especially in the enabler criteria. The authors concluded that ISO 9001 enables getting a better score on the EFQM model.

Although QMS assessors should provide a more neutral perspective than the opinions of quality managers, the use of perceptual data related to performance may have a bias affect the study results.

Further research is therefore necessary to analyze the relationship and the performance of both ISO 9001 and EFQM models and the use of empirical data from the external evaluations carried out by the independent assessors should be exploited.

This exploratory research aims to help close the two literature gaps identified: To study ISO 9001 International Standard and EFQM Business Excellence Model in conjunction and to minimize the possible bias of perceptual data based on quality managers or EFQM assessors opinions.

\section{RESEARCH RESULTS}

To access the information required for this exploratory research the following sources were used: 
- The list of organizations that have been recognized with EFQM Model in Portugal is available from APQ - Portuguese Association for Quality that is EFQM Portuguese National Partner organization (APQ, 2014). The list of organizations that have been awarded some recognition with the Portuguese Quality Award (PEX-SPQ) in line with the EFQM Award is available from IPQ - Portuguese Institute for Quality (IPQ, 2014). A total of 61 organizations is present in the sum of these two sources. However, some organizations are today no more in business or certified or it was not possible to confirm the relevant information, so 9 were eliminated, remaining 52 organizations as the available sample for this research.

- Confirmation that the 52 organizations mentioned in the previous paragraph are indeed ISO 9001 certified and information on the year of their first certification was collected from IPAC - Portuguese Institute for Accreditation register of accredited certified organizations (IPAC, 2014).

The variables were codified as "Y ISO 9001" representing the number of years since the first ISO 9001 certification of the organization and "L EFQM " for the highest Level of EFQM recognition achieved (see Tables 2 and 3).

Table 2 - Y ISO 9001 variable values (quantitative discrete variable)

\begin{tabular}{|l|l|l|l|l|l|}
\hline $\begin{array}{l}\text { Period of ISO } \\
\text { 9001 } \\
\text { certification }\end{array}$ & 2010-2014 & 2005-2009 & 2000-2004 & 1995-1999 & Until 1994 \\
\hline Y 9001 value & 1 & 2 & 3 & & 5 \\
\hline
\end{tabular}

Table 3 - L EFQM variable values (ordinal variable)

\begin{tabular}{|l|l|l|l|l|l|}
\hline $\begin{array}{l}\text { Highest Level } \\
\text { achieved with } \\
\text { EFQM model }\end{array}$ & $\begin{array}{l}\text { Recognized } \\
\text { for } \\
\text { Excellence }\end{array}$ & $\begin{array}{l}\text { Committed } \\
\text { to } \\
\text { Excellence }\end{array}$ & $\begin{array}{l}\text { Excellence } \\
\text { Award Finalist }\end{array}$ & $\begin{array}{l}\text { Excellence } \\
\text { Award Silver } \\
\text { Prize }\end{array}$ & $\begin{array}{l}\text { Excellence } \\
\text { Award Gold } \\
\text { Prize }\end{array}$ \\
\hline L EFQM value & 1 & 2 & 3 & 4 & 5 \\
\hline
\end{tabular}

Table 4 - Case Processing Summary

\begin{tabular}{|l|r|r|r|}
\hline L EFQM & Frequency & Percent & \multicolumn{1}{|c|}{ Cumulative Percent } \\
\hline Recognized for Excellence & 6 & 11,5 & 11,5 \\
\hline Committed to Excellence & 34 & 65,4 & 76,9 \\
\hline Excellence Award Finalist & 2 & 3,8 & 80,8 \\
\hline $\begin{array}{l}\text { Excellence Award Silver } \\
\text { Prize }\end{array}$ & 5 & 9,6 & 90,4 \\
\hline $\begin{array}{l}\text { Excellence Award Gold } \\
\text { Prize }\end{array}$ & 5 & 9,6 & 100,0 \\
\hline
\end{tabular}


A brief descriptive statistics of the data show that most of these certified organizations have so far achieved the Committed to Excellence recognition level as presented in Table 4.

For the statistical treatment of data, Statistical Package for Social Sciences 20 (SPSS) was used.

First, sample normality was tested with Kolmogorov-Smirnov test that is recommended for sample size above 30 (Pestana and Gageiro, 2008) as in this situation. In case the data have a normal distribution we can use parametric tests (also called T Test) and in case this does not occur we should use non-parametric tests.

The results of Kolmogorov-Smirnov test, presented in Table 5, show a value of "Sig. 0.002" for variable Y ISO 9001 and "Sig. 0.000" for variable L EFQM, both smaller than 0.05 . By the Kolmogorov-Smirnov test, we reach the conclusions that these data does not follow a normal distribution so we must use non-parametric tests.

Table 5 - One-Sample Kolmogorov-Smirnov Test

\begin{tabular}{|c|c|c|}
\hline Parameter & $\begin{array}{l}\text { Y ISO 9001 (YEARS OF } \\
\text { CERTIFICATION) }\end{array}$ & $\begin{array}{l}\text { L EFQM } \\
\text { (RECOGNITION LEVEL) }\end{array}$ \\
\hline $\mathrm{N}$ & 52 & 52 \\
\hline Normal Parameters: Mean & 2.54 & 2.62 \\
\hline $\begin{array}{l}\text { Normal Parameters: Std. } \\
\text { Deviation }\end{array}$ & 1.275 & 1.484 \\
\hline Kolmogorov-Smirnov Z & 1.873 & 3.101 \\
\hline Asymp. Sig. (2-tailed) & 0.002 & 0.000 \\
\hline Exact Sig. (2-tailed) & 0.001 & 0.000 \\
\hline
\end{tabular}

Correlation coefficient Spearman Rho was used to measure the intensity of the relationship between ordinal variables and do not require that data provides from normal distributions. Spearman coefficient varies between -1 and 1 and as near the values are from these extremes the stronger is the linear association between the variables. The sign of the Spearman Rho correlation indicates the direction of association between $\mathrm{X}$ (the independent variable) and $\mathrm{Y}$ (the dependent variable). If $\mathrm{Y}$ tends to increase when $\mathrm{X}$ increases, the Spearman Rho correlation coefficient is positive. If $\mathrm{Y}$ tends to decrease when $\mathrm{X}$ increases, the Spearman Rho correlation coefficient is negative. If the value is zero, this means there is no linear relationship between the variables. SPSS with significance test at 0.01 level was used (2-tailed) and the result for Correlation coefficient Spearman Rho between the two variables was 0.392 , as presented in Table 6 . 
Table 6 - SPSS Output results for Spearman Correlation coefficient between variables Y ISO 9001 and L EFQM

\begin{tabular}{|l|l|r|}
\hline $\begin{array}{l}\text { Spearman's Rho Correlation } \\
\text { Coefficient }\end{array}$ & $\begin{array}{l}\text { Y ISO 9001 (YEARS OF } \\
\text { CERTIFICATION) }\end{array}$ & $\begin{array}{l}\text { L EFQM } \\
\text { (RECOGNITION LEVEL) }\end{array}$ \\
\hline Y ISO 9001 & 1,000 & 0,392 \\
\hline L EFQM & 0,392 & 1,000 \\
\hline
\end{tabular}

The interpretation of the results achieved with Correlation coefficient Spearman Rho is similar to the one when Correlation coefficient Pearson $\mathrm{R}$ is used. If Spearman is between 0.2 and 0.6 we can state that the linear association between the two variables is positively moderate (Pestana and Gageiro, 2008).

Since we have a result for Correlation coefficient Spearman Rho of 0.392 we can state that there is a moderate positive correlation between the two variables and in case we use Y ISO 9001 as the independent variable and L EFQM as the dependent variable, the higher the number of Years of ISO 9001 certification, the higher the results of the organization EFQM Model evaluation and recognition.

ISO 9001 International Standard is based on the PDCA cycle so it is indeed expected that organizations with higher number of years of ISO 9001 certification have gone through more improvement cycles and so their Quality Management Systems should have an increased maturity level, as shown by EFQM model evaluations results and achieved levels.

\section{CONCLUSION}

\subsection{Discussion of results}

ISO 9001 is an International Standard of worldwide acceptance aiming for customer satisfaction and continuous improvement. There is an increased adoption of this Quality Management International Standard worldwide and academics generally agree that its implementation may lead to several benefits like improved performance and results. Studies have found the internal motivations led to better results than external motivations (Tarí, Molina-Azorín and Heras, 2012) but there are control factors (e.g., industry size and type, applicable environmental laws and cultural issues) and other dimensions that should be investigated, like the way Management Systems are interpreted and implemented (Christman and Taylor, 2006; Yin and Schmeidler, 2009) and the time delay between implementation and improved results. And, in fact, some authors (e.g. Corbett and Yeung, 2008) considering the impact of meta-standards like ISO 9001, find it surprisingly there is no more scholarly research on most of those standards. 
With this research, a detailed comparison between ISO 9001 International Standard and EFQM Business Excellence Model was made. This last model was used to investigate if there is a relationship between organizations ISO 9001 years since first certification and the results those organizations achieved when evaluated with EFQM Business Excellence Model.

Since the two variables did not follow a normal distribution, Correlation coefficient Spearman Rho was used and the result was 0.392, allowing for the conclusion that there is indeed a moderate positive correlation between the two variables.

Using Y ISO 9001 as the independent variable and L EFQM as the dependent variable, the higher the number of Years of ISO 9001 certification, the higher the results of the organization EFQM Model evaluation results, which is in line with the results expected from literature review. ISO 9001 International Standard is based on the PDCA cycle so organizations with higher number of years of ISO 9001 certification have gone through more PDCA improvement cycles. It is therefore expected that their Quality Management Systems should have an increased maturity level, as shown by higher EFQM model evaluations results and recognition levels.

These findings come into support of the assumption that ISO 9001 International Standard by incorporating many of the principles present on the EFQM Business Excellence model is consistent with this model and can be considered as a step towards that direction. They support the results reported by Heras, Casadesus and Marimón (2011) that ISO 9001 enables getting a better score on the EFQM model. This research also gives additional insights on conjunct studies of ISO 9001 International Standard and EFQM Business Excellence Model and minimizes the possible bias of studies using perceptual data based on quality managers or EFQM assessors opinions, by using the external evaluations carried out by the independent EFQM assessors,

\subsection{Research limitations and suggestions for future work}

Since International Standards and Business Excellence Models are dynamic, changes have and will occur during the years. This a limitation for the analysis made in this article and more in-depth studies like experimental design or a longitudinal quasi-experimental design could be used to confirm acceptation of the plausible positive relationship between the two studied variables.

Future studies should be made with the expected ISO 9001:2015 International Standard, for scientific academic validation of its expected higher positive impacts and outcomes and to confirm if it is indeed, a strong step towards Business Excellence and sustainable success. 


\section{REFERENCES}

APQ, 2014. [online] Available at: http://www.apq.pt/portal/EFQM/Lista, [Accessed 2014.12.20].

Boiral, O., 2012. ISO 9000 and Organizational Effectiveness: A Systematic Review. Quality Management Journal, 19(3), pp.16-37.

Boulter, L., Bendell, T. and Dahlgaard, J.J., 2013. Total quality beyond North America: A comparative analysis of the performance of European Excellence Award winners. International Journal of Operations and Production Management, 33(2), pp.197-215.

Christmann, P. and Taylor, G., 2006. Firm self-regulation through international certifiable standards: Determinants of symbolic versus substantive implementation. Journal of International Business Studies, 37, pp.863-883.

Corbett, C.J. and Yeung, A.C.L., 2008. Special issue on meta-standards in operations management: cross disciplinary perspectives. International Journal of Production Economics, 113(1), pp. 1-2.

Curkovic, S., Melnyk, S.A., Calantone, R. and Handfield, R.B., 2000. Validating the Malcolm Baldrige National Quality Framework through structural equation modeling. International Journal of Production Research, 38(4), pp.765-791.

Dahlgaard-Park, S.M., 2008. Reviewing the European Excellence Model from a management control view, The TQM Journal, 20(2), pp.98-119.

EFQM, 2012a. EFQM Excellence Model, Your Guide to the Model 2013. Brussels: EFQM.

EFQM, 2012b. EFQM Fundamentals Concepts of Excellence, Model 2013. Brussels: EFQM.

EFQM, 2012c. EFQM, Excellence in Action. Brussels: EFQM.

EFQM, 2011. Benefits of using the EFQM Excellence Model 2010. [online] Available at: http://www.efqm.org [Accessed 2011.02.26].

EFQM, 2014. [online] Available at: http://www.efqm.org/efqm-model/modelcriteria, [Accessed 2015.03.20].

EFQM, 2015. [online] Available at: http://www.efqm.org/efqm-model/modelcriteria, [Accessed 2015.03.20].

George, C., Cooper, F. and Douglas, A., 2003. Implementing the EFQM Excellence model in a local authority. Managerial Auditing Journal, 18(2), pp. 122-127.

Fonseca, L., 2015. From Quality Gurus and TQM to ISO 9001:2015: a review of several quality paths. International Journal for Quality Research, 9(1), pp.167180. 
Gutiérrez, L,J.G., Torres, I.T. and Molina, V.B., 2010. Quality management initiatives in Europe: An empirical analysis according to their structural elements. Total Quality Management \& Business Excellence, 21(6), pp.577-601.

Hansson, J. and Eriksson, H., 2002. The impact of TQM on financial performance. Measuring Business Excellence, 6(4), pp.44-54.

Heras, I., 2006. How quality management models influence company results. Total Quality Management \& Business Excellence, 17(6), pp.775-794.

Heras, I.S and Boiral, O., 2013. ISO 9001 and ISO 14001: Towards a Research Agenda on Management System Standards. International Journal of Management Reviews, 15(1), pp.47-65.

Heras, I.S., Casadesus, M. and Marimón, F., 2011. The impact of ISO 9001 standard and the EFQM model: The view of the assessors. Total Quality Management \& Business Excellence, 22(2), pp.197-218

IPAC, 2014, [online] Available at:

http://www.ipac.pt/pesquisa/pesq_empcertif.asp, [Accessed 2014.12.20].

IPQ, 2014. [online] Available at:

http://www1.ipq.pt/pt/spq/pex/pex_spq/Pages/PEX-SPQ.aspx, [Accessed 2014.12.20].

ISO, 2014. ISO/DIS 9001, Quality management systems — Requirements, Geneva: International Organization for Standardization.

ISO, 2005. ISO 9000:2005, International Standard, Quality management systems - Fundamentals and vocabulary. Geneva: International Organization for Standardization.

ISO, ISO TC/176, 2014. [online] Available at: http://

www.iso.org/iso/iso_technical_committee?commid=53882, [Accessed 2014.10.01].

ISO, 2014. ISO Survey 2013. [online] Available at: http://www.iso.org [Accessed 2014.10.01].

Jacob, R., Madu, C.N. and Tang, C., 2004. An empirical assessment of the financial performance of Malcolm Baldrige Award winners. International Journal of Quality \& Reliability Management, 21(8), pp.897-914.

Karapetrovic, S., Casadesus, M. and Heras, I. (2008). What happened to the ISO 9000 lustre? An eight-year study. Working Paper, Departament d'Organitzacio', Gestio' empresarial I Desenvolupament de producte, Universitat de Girona, Spain.

Kim, D-Y., Kumar, V. and Murphy, S.A., 2008. European Foundation for Quality Management (EFQM) business excellence model: a literature review and future research agenda, Halifax, Nova Scotia: Sprott School of Business, Carleton University. 
Kiauta, M., 2012. Idea of Quality versus idea of Excellence. Quality Innovation Prosperity / Kvalita Inovácia Prosperita, 16 (2), pp.103-114.

Levine, D. and Toffel, M.W., 2010. Quality Management and Job Quality: How the ISO 9001 Standard for Quality Management Systems Affects Employers and Employees, Cambridge, Massachusetts: Harvard Business School.

Marconi, M.D. and Lakatos, E.M., 2003. Fundamentos de Metodologia Científica - $5^{a} E d$. São Paulo: Atlas.

Martínez-Costa, M., Choi., T.Y., Martínez, J.A. and Martínez-Lorente, A.R., 2009. ISO 9000/1994, ISO 9001/2000 and TQM: The performance debate revisited, Journal of Operations Management, 27 (6), pp.495-511.

Pestana, A.H. and Gajeiro, J.N., 2008. Análise de Dados para as Ciências Sociais - A Complementaridade do SPSS, Lisboa: Edições Silabo.

Powell, T.C., 1995. TQM as competitive advantage: A review and empirical study. Strategic Management Journal, 16(1), pp.15-37.

Sila, I. and Ebrahimpour, M., 2005. Critical linkages among TQM factors and business results. International Journal of Operations \& Production Management, 25(11), pp.1123-1155.

Tarí, J.J., Molina-Azorín, J.F. and Heras, I., 2012. Benefits of the ISO 9001 and ISO 14001 standards: A literature review. Journal of Industrial Engineering and Management, 5(2), pp.297-322.

Van der Wiele, A., Williams, A.R.T. and Dale, B.G., 2000. ISO 9000 series registration to business excellence: the migratory path, Business Process Management Journal, 6(5), pp.417-427.

Yin, $\mathrm{H}$ and Schmeidler, P.J., 2009. Why do standardized ISO 14001 environmental management systems lead to heterogeneous environmental outcomes? Business Strategy and the Environment, 18, pp.469-486

\section{ABOUT THE AUTHOR}

Luis Miguel Ciravegna Fonseca, PhD - ASQ Fellow, Adjunct Professor, ISEPIPP, School of Engineering, Department of Mechanical Engineering (Industrial Management), Polytechnic of Porto, Portugal. His main research areas are quality, management, sustainability, social responsibility and industrial engineering and management. e-mail: 1mf@isep.ipp.pt 